\title{
What Features Should Have Firms To Be Credited By Banks - The Case Of Kosovo
}

\author{
ENVER BAJÇINCA \\ PhD Candidate \\ European University of Tirana, \\ Faculty of Economics, Department of Finances, \\ e_bajcinca@yahoo.com
}

DOI:10.5901/mjss.2014.v5n19p439

\begin{abstract}
Business finance depends mainly on the development of the financial market and its instruments in country. To realize the investment and of their development activities firms was not enough internal finances, but they are forced to use external finances. The main form of external finances in developing countries is bank credit. The purpose of this paper is to analyze when firms need to finance investment and other activities are there any differences between firms of different sizes in acquiring bank loans and does structure of their funding sources is different. Consequently research question is: Does firm size impact on access to bank loans? So the main hypothesis to be tested in the paper is: firm size is positively correlated to access to bank loans. To test the hypothesis and to research about a purpose of the paper I used data collected from the survey of 500 firms in Kosovo, which was conducted by Businesses Support Center of Kosovo. The main results of the paper are that there is a positive relationship between firm size and access to bank loans. As larger is the firm as easier access to bank loans. Small firms are more limited in access to bank loans. Consequently, firm size determines the differences in the structure of the sources of finance for firms. Small firms have to rely more on internal finances, and because are more limited access in finances, they should be directed to the family and friends. Also, in order to obtain credit, small firms must provide collateral three times the value of the loan, while medium firms and large will provide for less than half of small firms do. Other factors that affect firms in acquiring loans from banks are trade and services sectors, imports and performance of the firm. The manufacture sector, export, having a written business plan and area where firm operates didn't find to have significance impact in acquiring loans.
\end{abstract}

Keywords: firm size, financing, factors, banks, Kosovo

\section{Literature review}

Numerous studies have discussed that small and medium enterprises (SMEs1) are financially more limited than large firms and are less likely to have access to formal sources of financing. Until recently, however, was a little evidence of countrylevel degree to which size is a crucial factor in determining the barriers to business development or access to finance.

Target efforts toward sector of small and medium enterprises often based on the premise that (i) SMEs are the engine of growth, but (ii) market imperfectivity and institutional weaknesses impede their development. Skeptics call into question the effectiveness of this policy and focus on empirical evidence either in favor of large firms or a blind policy approach to firm size (Biggs 2002, Beck \& Asli Demirguc-Kunt, 2006). While many studies in the country and microeconomic level have assessed the importance of SMEs in economic development and industrialization process (Snodgrass \&Biggs 1996, Beck and Asli Demirguc-Kunt, 2006).

If firms are face by limited access to external sources of funding they may not be able to invest against their will to do it, unless internal financial resources in available are sufficient. In these circumstances, large firms that are able to receive financial resources can not use those by profitability; on the other hand, small firms would find opportunities that can be good profitability, but can not find financial resources.

\footnotetext{
${ }_{1}^{1}$ SME - small and medium. Their size in Kosovo is defined by Law no. 2005/02-L5 and Law no. 03L/-031 who fit that makes sharing OECD and the European Commission. This is based on the number of employees: 1-9 employees = micro enterprise; 10 to 49 employees = small enterprise; 50-249 = medium enterprise workers and 250 more employees = large enterprise. In most cases, instead of expressing paper will use the term enterprise firm and their meaning is the same
} 
Theoretical and empirical considerations show that the size, age and ownership are the most reliable predictors of financial barriers (Beck, Demirguc-Kunt, Leaven dhe Makimovic 2006).

Older, larger and foreign-owned firms report lower financial barriers. In the case of fixed transaction costs and information asymmetry, small firms with demand for smaller loans face higher transaction costs and risk facing higher prices since they are typically the most inscrutable and have less opportunity in providing collateral.

If a firm has easy access to external funds, the internal generated funds should not constitute the main source of finance for investment. In addition, firms with a better financial situation, perspective and good governance practices need to find external funds more easily accessible. On the other hand, if more companies rely on self-financing, it means that either may be present financial constraints, or foreign capital is not easily achieved or even is unavailable or the circumstances of the enterprise make borrowing more expensive funds.

Access to finance and their cost is often ranked as one of the most restrictive features of the business environment of SMEs. Specifically, the cost of finance is ranked in over $35 \%$ of small and medium enterprises as the main limitation of growth in a sample of 71 countries, the bulk of them are in development, which is more than any other characteristic the business environment, including the tax rate and macroeconomic instability, also ranked by many SMEs as key growth restrictions (Beck, 2007).

The higher obstacles of financing reported by small firms compared with large ones also reflected in the forms of financing. While small firms finance less than $10 \%$ of their needs from finance investment banking, large firms finance more than $20 \%$ from bank loans. Large firms have advantages similar, although not as strong, in commercial loans and finance development, while small firms seems that most fund financing with equity and informal finance, compared with large firms.

Small firms finance their investments with lower participation from formal sources of external finances (Beck, DemirgucKunt, Laeven dhe Maksimovic, 2004) they average finance its investments with banks credit by 13 percentage points less than large firms. While there are no significant differences with in case of lease financing, large firms finance investment with a greater participation shares and - perhaps surprisingly-with development finance than smaller firms. On the other hand, smaller firms finance most of the funding to informal sources of finance, such as usurers or family and friends (Beck \& Demirguc-Kunt, 2006).

The difference between small firms and large is at least as great or even greater for some specific financing obstacles, such as collateral requirements, bank documents, interest rate payments, the need for special connection and lack bank lending resources. Transaction costs and information asymmetries cause changes to access to finance for firms of different size. Fixed cost of transaction evaluation, processing and monitoring of credits resulting in cost reduction per unit as loan size increases. These fixed transaction costs exist at the level of transaction, customer, institution and even the financial system. Individual credit rating implies a cost that is at least partly independent of the loan amount. Maintaining customer relationship over time and various financial products, including credit, deposit and savings services, implies costs that are partly orthogonal to the number and amount of financial transactions with the client. These fixed transaction costs cause a difference between funding costs and financial institutions lending rate that they charge borrowers. At the time of uncertain investment returns, high transaction costs resulting in higher credit costs which could raise the possibility that the borrowers can not pay due to very high loads of debt payment. Before interest rate rises in the market clearing rate, financial institutions can ration at a rate of interest lower than the market equilibrium rate because the higher rates of interest will lead to lower debt payments expected (Williamson 1987, Beck 2007)

While transaction costs are restrictive for all borrowers, there are evidences that they are even more restrictive to small and medium enterprises. Their different characteristics and relative inscrutability increase the costs of evaluation and monitoring. Despite other credit categories, such as consumer credit and mortgage lending, SME lending product is still considered high-cost lending. More specifically, despite other credit products that can be reduced to simple transactions, lending to SMEs is still often depends on relationships between borrowers and creditors (Berger dhe Udell, 1998, 2006, Beck 2007).

Apart from the transaction costs the field for small and medium size enterprise is limited by the risk of failure. The risk of failure may be due to specific or systemic borrowers. Following the risk of specifics the borrowers and more specifically the risks arising from asymmetric information between borrowers and creditors. If the debtor is deprived of information for his project or his efforts and creditors may provide this information only in a higher cost prohibitive, this can lead to two different sources of risk: 


\section{Adverse selection and Moral Hazard}

Adverse selection refers to the difficulty of selecting the best credit risk ex-ante, while moral hazard refers to the inability of creditors to effectively implement the approved credit contract ex post. Although such risk can be offset by increasing interest rates, this would increase adverse selection and moral hazard. Once interest rates rise, this will attract more risky borrowers in race to undertake riskier projects with a high probability of failure. Inability to use interest rates as creditors pull selective technology to use selection tools that are not associated with interest as collateral, guarantees or assessment based on audited information. In its last implication, however, creditors will ration loans before allowing the interest rate to rise to market clearing level, which was first presented by Stigliz and Weiss (1981)

Lending to SMEs, as in the case of transaction costs, is more affected by the inability to manage risks than other credit products. Compared with large firms, SMEs are usually inscrutable, are less likely to be able to decide the collateral and often do not have audited financial reports that allow a better view of the firm and projected earnings.

The demand for creditable funds is a positive function of the expected returns of investment projects and a negative function of the interest rate of credit and voluntarily self-exluded. While a theory and empirical work suggests that market power can force banks invest in long-term relationships with small and mighty because they know they can recover the initial investment at a later stage (Petersen dhe Rajan, 1995; Bonaccorsi di Patti dhe Dell'Ariccia, 2004), other empirical work focuses on the effect of sound competition in the credit available to SMEs (Cetorelli dhe Strahan, 2004; Beck, DemirguçKunt dhe Maksimoviç, 2004a, Beck 2007).

\section{The purpose and objectives of the study}

The purpose of this paper is to analyze when firms need to finance investment and other activities are there differences between firms of different sizes in acquiring bank loans and a different structure of their funding sources. The objectives of the paper are:

To identify the differences between small firms and large for access to bank loans and understanding the financial constraints of small firms;

To identify the factors that affect firms in obtaining bank loans;

\section{The research question, hypothesis and methodology of the paper}

The main research question of this research paper is:

Does the impact of firm size in access to bank loans? Conqesuently it is drawn the main hypothesis for testing in our model:

"The size of the firm is positively correlated to access to bank loans."

Another question of the paper is what the characteristics of firm are that affects banks to approve loan?

The data used in this paper were collected as part of a broader survey of 500 firms in Kosovo, carried out by Business Support Center Kosovo. The sample was drawn randomly from the register of businesses held in the Ministry of Trade and Industry / Business Registration Agency. This randomly stratified sample allows us to draw general conclusions for the whole population of firms in Kosovo. The sample includes firms of all regions of Kosovo and is stratified into three main sectors, in order to reflect differences between production, trade and services. Statistical stratification is done in terms of size, in order to ensure representation of firms based on sample size. Interviews were conducted face - to-face with key people in each firm, mainly owner / managers or financial managers. Respondents were asked to provide quantitative and qualitative response to the intrinsic characteristics of the respective firm (years in business, location, firm size in terms of employees, the sector which operate etc.), Indicators of financial performance and investment (profitability and the level of investment, etc.) and information about success on their requirements for bank loans.

\section{The banking sector in Kosovo, description of research statistics, model and research results}

\subsection{The banking sector in Kosovo}


After the war in Kosovo, 1999, the banking sector has started from scratch making a break from the past and all the efforts have been directed at strengthening public confidence on that after having a bitter experience from the loss of deposits in banks of former Yugoslavia. The banking sector plays a dominant role in the structure of the financial system of Kosovo with $73 \%$ of the total assets of the financial sector. The banking sector has experienced during 2013, an increase of $8 \%$ and an increase better compared to that of 2012 when the increase was $6 \%$. In Kosovo currently operate nine commercial banks. Some data placing most about banking sector are given in Table 1.

Table 1: Selected indicators of banking sector

\begin{tabular}{|l|l|l|l|l|l|}
\hline & 2009 & 2010 & 2011 & 2012 & 2013 \\
\hline GDP (mln. €) & 4007.8 & 4291.1 & 4769.8 & 4961.4 & $5115.20^{*}$ \\
\hline Number of banks & 8 & 8 & 8 & 8 & 9 \\
\hline Total assets of banking sector (\%PBB $\left.{ }^{\star *}\right)$ & & $51.7 \%$ & $52.4 \%$ & $53.5 \%$ & $54.5 \%$ \\
\hline Deposits (\% GDP) & $43.5 \%$ & $45.1 \%$ & $44.1 \%$ & $45.9 \%$ & $47.9 \%$ \\
\hline Loans (mln. €) & 1289 & 1458.7 & 1698.1 & 1763.4 & 1805.8 \\
\hline Loans for private firms (\% e GDP) & & $23.6 \%$ & $23.9 \%$ & $23.6 \%$ & $23.4 \%$ \\
\hline
\end{tabular}

Source: Central Bank of Kosovo (2013, Quarterly Assesment of Eeconomy, Q4)

${ }^{*}$ CBK estimated

${ }^{*}$ GDP - Gross Domestic Product

The main sources of financing of commercial banks in Kosovo are deposits by 79\% (CBK, 2014 Financial Stability Report). Major participation in the formation of these deposits comprises households with $72 \%$, while private businesses sector contribute to 16\% (CBK, 2014 quarterly assessment of the economy). However this potential financial banks use deposits formed by more businesses (67\%) compared to households (31\%). But this gap is being reduced because businesses have a negative trend in the share of loans, while households positive trend, as shown in the following table. Loans to private businesses mark a low around $23-24 \%$ of GDP, which is an indicator of financial performance and growth limitation of firms in Kosovo based on the view that firms are larger in countries with high levels of private credit relative to GDP (for more details see Beck \& Demirguc-Kunt, 2006). Also, Kosovo marks the lowest level of the ratio of loans to GDP businesses in the region1.

Table 2: Dynamics of deposits and loans in years

\begin{tabular}{|l|l|l|l|l|l|l|l|}
\hline & 2000 & 2001 & 2002 & 2010 & 2011 & 2012 & 2013 \\
\hline Loans/deposits ratio (\%) & 5.3 & 20.2 & 45.3 & 75.3 & 80.7 & 77.4 & 73.74 \\
\hline Business loans / T*(\%) & 100 & 93.4 & 83.1 & 69.3 & 67.1 & 66.5 & 67.0 \\
\hline Households Loans/TL (\%) & 0 & 6.6 & 16.8 & 29.8 & 30.3 & 31.0 & 31.0 \\
\hline
\end{tabular}

Source: CBK, The data processed by the author of the paper (Monthly statistical bulletins of different years) *TL - Total Loans

There is a slight increase in demand for loans by enterprises, dominated by SMEs requirements, while demand from large enterprises declined. On the other hand there is a tightening of bank credit activities, the reason given by banks cautious expectations about future developments in the country's general economic and also foreign banks operating in Kosovo exposed to increasing demands of regulatory capital at the their headquarters (CBK, 2014: Financial Stability Report) Also financial potential of the banking sector in Kosovo is limited because the near 2 billion euros from privatization fund, which

1 In 2011 SME loan / GDP report was 41.2\% in Albania, 46\% - Bosnia, 47.5\% - Serbia, 49.9\% - Macedonia and 121.2\% - Montenegro black. Source: RIINVEST 2012, Bajçinca, E. 2013. 
is frozen and Kosovo Pension Trust, the bulk of which is placed in foreign markets outside turnover of Kosovo financial system (for more details see Bajçinca, E. 2013).

\subsection{Statistics Descriptive}

Let's view some results of research with firms in Kosovo. Table 3 presents an overview of the firms investing activities for the years 2010-20121. In 2010, the percentage of firms that have had investment activities was 24.2, considered to be the lowest in Kosovo after the war 2, to have an increase in 2011 with $48.8 \%$ of firms and a drop back to $37.2 \%$ of firms in the sample for in 2012. During the first years after the war there has been a boom in investment activity by the firms that contributed to their development and growth, while in recent years there is a struggle that can be from reaching the border firms opportunities and may also have felt the international financial crisis on the business activities of firms. As the structure of firms by size in Kosovo is, it approximately reflected in the participation of firms have investments, where it is remarkable dominance of micro firms, followed by small firms. It is undersetable that the highest average volumes of investments of large firms have been diminishing as it shrinks the size of the firm, to micro enterprises which have lower average.

Table 3 Investments of firms by size in Kosovo, for the years 2010 - 2012

$\begin{array}{lc}\text { Number of firms in the sample } & \text { Participation } \\ \text { that have investment } & \text { in } \%\end{array}$

The average Participation amount of in the total investment volume of

(€) investments

$(\%)$

\begin{tabular}{l|llll|}
\hline & & & & \\
Micro Firms & 136 & 73 & 10,679 & 13 \\
Small Firms & 31 & 17 & 175,821 & 47 \\
Medium Firms & 15 & 8 & 253,333 & 33 \\
Large Firms & 4 & 2 & 220,000 & 8 \\
Total & 186 & 100 & 62,273 & 100 \\
2011 - Investment Activities, 48.8 \% of firms & & & \\
Micro Firms & 178 & 73 & 11,098 & 6 \\
Small Firms & 44 & 18 & 192,333 & 25 \\
Medium Firms & 17 & 7 & 508,000 & 25 \\
Large Firms & 5 & 2 & $3,009,750$ & 44 \\
Total & 244 & 100 & 139,848 & 100 \\
2010 - Investment Activities, 24.2 \% of firms & 95 & & & \\
Micro Firms & 20 & 78 & 19,893 & 11 \\
Small Firms & 5 & 17 & 131,813 & 15 \\
Medium Firms & 5 & 4 & 349,171 & 10 \\
Large Firms & 1 & 1 & $11,000,000$ & 64 \\
Total & 121 & 100 & 142,743 & 100 \\
\cline { 2 - 6 }
\end{tabular}

It is evident, since the micro and small firms dominate investment activities in number, are also expected their demands to the banks to finance investment projects. There is a contradiction here. Although small and micro firms dominate in number

\footnotetext{
${ }^{1}$ For more detail, the results of the survey with SMEs see reports of research with SMEs (BSC Kosovo, 2011, 2012, 2013)

${ }^{2}$ About investment activities for years 2001 - 2005, see survey research reports with SMEs in Kosovo, Riinvest 2006
} 
of loans that use from commercial banks, however they are limited in terms of the realization of overall loan volume requiring the bank, either in the absence of collateral that can provide or because there are more unknowns in the market and banks in general, so consequently faced with obstacles in the realization of planned investments.

The results from the research show that small firms rely more on domestic sources to finance their investments, access to bank loans are smaller than large enterprises and for this reason they are oriented on the use of support from family and friends participating with $8.2 \%$ of small business financing. If we take SMEs generally, we would noted that they have 13.6 percentage points of their funding from bank loans less compared by large enterprises that is in line with international findings Beck\&Demirgu-Kunt (2006). While the internal sources of financing participating about 5 percentage points higher at small firms than large enterprises, despite being well within small firms are financially limited (Butters\&Linter 1945, Carpenter \& Petersen 2001). The analysis reveals that there is a positive empirical relationship between firm size and access to bank loans, the smaller company's participation in the financing bank loans is lower and vice versa.

Table 4: Sources of funding for investment in Kosovo firms by size, in\%

\begin{tabular}{|l|l|l|l|l|l|}
\hline & & & & & $\begin{array}{l}\text { Differences } \\
\text { (SME- Large Firms) në } \\
\text { pp.* }\end{array}$ \\
& Small Firms & Medium Firms & Large Firms & SME & \\
\hline Own sources & 71.8 & 70 & 66.7 & 71.6 & 4.9 \\
\hline Banks Loans & 18.5 & 30 & 33.3 & 19.7 & -13.6 \\
\hline Donations & 1 & 0 & 0 & 0.7 & 0.7 \\
\hline Family and friends & 8.15 & 0 & 0 & 7.5 & 7.5 \\
\hline Usury & 0 & 0 & 0 & 0 & 0 \\
\hline FDI & 0.3 & 0 & 0 & 0.3 & 0.3 \\
\hline Other sources & 0.25 & 0 & 0 & 0.2 & 0.2 \\
\hline Total & 100 & 100 & 100 & 100 & \\
\hline
\end{tabular}

*Pp - point of percentage

FDI- Foreign Dirct Investment

About $35.1 \%$ of businesses in Kosovo appreciate access to credit as a major obstacle or hindrance to the development of the business, which is in line with international findings.

Research evidence shows that not all firms that have demanded loans have managed to get it. Of all the firms in the sample included 195 who applied, 149 of them (76.4\%) have received loans and 46 (23.6\%) were rejected. If analyzed by size the firms that have applied, it would be note that 184 small loans received 139 (75.5.6\%) were rejected while $45(24.5 \%)$ of them. From medium enterprises included in the sample had nine firms applied for loans, 8 from them (89\%) have received and $1(11 \%)$ was rejected, while two large firms that have applied had managed to take out loans.

Responses of firms in the reasons for denial of credit, in most cases (90\%) dominates the impossibility of providing collateral and in some cases the lack of a business plan and the impossibility of delivery of documents that requires banks. Also at the firms, there is a self-selection in decision-making occasion to apply for loans, which we call the discouraged group. When firms are asked about the reasons for not applying for loans, over half of SMEs (53.7\%) stated that they did not need loans, $47.2 \%$ complained about high interest rates, $8.4 \%$ higher requirements for banks to offer collateral value and $8.4 \%$ of them indicated complex procedures for loan application. 1

Figure 1: Access to bank loans upon application, by size of firm

\footnotetext{
${ }^{1}$ Respondents were able to give more than one answer for the non-apply for loan.
} 


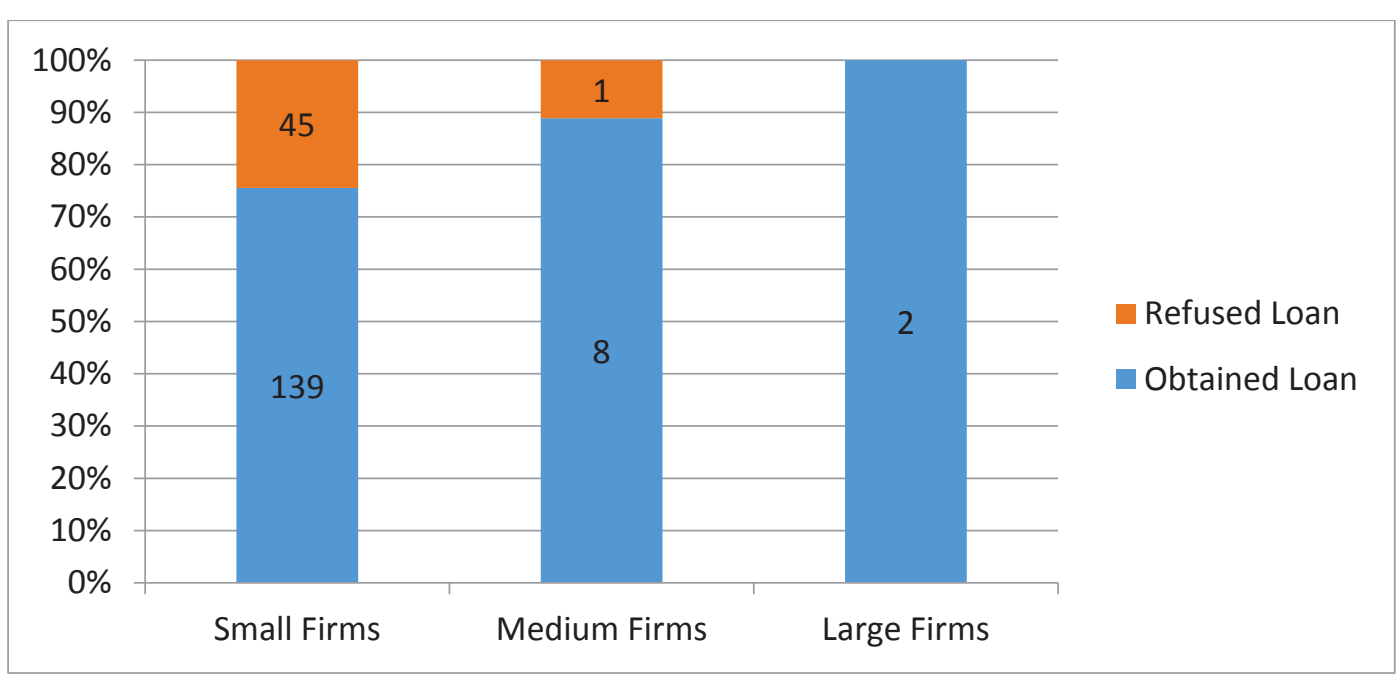

Based on survey data, an analysis was done for the coefficient of collateral, it shows that micro firms have average coefficient of collateral 1.39, small and medium enterprises 2.99 and 1.39 respectively, which according to ANOVA test results that the differences between the three groups were not statistically significant enterprises, while there is a significant difference between the averages of micro and small enterprises together on one side (3.01) and medium-sized enterprises on the other side (1.39) 1.

This shows that banks are quite conservative and want to be sure when deciding to lend to small firms. This may be the reason that some small firms complain about complex procedures when applying for loan. Also lending conditions in terms of loan repayment period vary between firms of different sizes. For example, the simple average return of credit for micro firms is 29.48 months for small firms 34.44 per month and for medium firms is 49

month. Although there are differences in the simple averages, there is no proving that these differences are statistically significant changes. Regarding the interest rate are not found significant differences of different sizes firms, the overall the rate ranges $13.5 \%$ on average.

\subsection{The model}

The database used for the purpose of this paper contains answers on questions asked to firms if they take loans from banks to fund its financing activities and other business activities by differentiating firms that applied for loans from those who do not have applied. From the sample of firms included in the survey, 195 of them had applied for loans. If the focus was only on firms that have received loans, it would be ignored the issue of selection of firms for lending. Some firms decided not to apply even if they need because they believed they would be rejected by the impossibility of meeting the requirements of bank 2 .

In order to analyze the issue of selection or the probability of firms that received loans from banks are taken into account all the firms that had applied for loans. For the purposes of this paper was used logistic regression model to determine the probability of obtaining loan by firms that applied. Firms that had taken bank loans were coded with figure 1 , and with figure 0 - firms that were not selected by banks to be lending upon application. Our aim was to test a model of how firm size affects the probability of obtaining bank credit when applying for loans. As the size factor is get the number of emploees in the firm. Besides size as explanatory variables is included age 3 of the firm.

\footnotetext{
${ }^{1}$ In the absence of data for collateral of large enterprises, it wasn't done the collateral coefficient for large enterprises

2 This can be seen by comparing the number of firms that have received bank loans with the number of firms that had investment activities 149/188

3 Years since the establishment of the firm until the time of the survey
} 
Besides the main hypothesis testing through logistic regression model, it is analyzed the impact of several factors for obtaining bank loans by firms such as the sectors in which the firm operates; manufacturing, trade and services being exporting or importing firm, the performance of firm, having a written business plan, employment growth, as well as areas where the company operates; urban or rural.

\subsection{Results of the survey}

Regression analyzes were performed in SPSS software package. To show off the results of the survey is used a logistic regression model. The procedure for testing the main hypothesis gave reliable results in connection with the explanatory variables on the dependent variable on significance level of $1 \%$. In this model the introduction of explanatory variables, the size and age, are explaining the model between 8.7 and $13 \%$. The model correctly predicts $76.9 \%$ of firms that have access to bank loans. Based on the results of the model in table 5 , it is noted that the size is significance within the limit of $5 \%$ (significance 0.023 ), while age has no acceptable level of significance (0.156) so that it interacts negatively on the size of the firm in terms of access to bank loans. Size has a positive empirical relationship in access to bank loans, thus increasing the number of employees to affect getting a bank loan with a factor of 1.248 .

Table 5: The impact of explanatory variables in obtaining banks loans

\begin{tabular}{|ll|l|l|l|l|l|l|}
\hline & B & S.E. & Wald & df & Sig. & Exp (B) \\
\hline Step 1a & Size & 0.222 & 0.097 & 5.195 & 1 & 0.023 & 1.248 \\
& Age & 0.045 & 0.032 & 2.017 & 1 & 0.156 & 1.046 \\
& Size by Age & -0.008 & 0.004 & 4.185 & 1 & 0.041 & 0.992 \\
& Constant & 0.264 & 0.372 & 0.503 & 1 & 0.478 & 1.302 \\
\hline
\end{tabular}

a. Variable(s) included in step 1: Size * Age .

Also through logistic regression model are analyzed the impact of several factors for obtaining credit from banks. This model correctly predicts the impact of the factors involved in making the loan at $79 \%$, which is a satisfactory level, presented in table 7. The correlation matrix, presented in Table 9 in appendix shows that correlation between individual explanatory variables are low, which is a good sign for not having multicollinearity effect. Apart from the influence of size, further analysis of our model gave results that other factors affecting firms in obtaining loans from banks are sector, where trade and services are more likelyhood to get loans from banks. Then other factors that affect firms in acquiring loans from banks are imports and performance of the firm. Importing firms and those with good performance are more likelyhood to obtain loans from banks. Although we should be careful firm performance, because the perception of performance can be given ex post the credit and the positive perception of turnover firms have the opportunity to feel as a relief after receiving the loan.

Table 6. Classification Table

\begin{tabular}{|c|c|c|c|c|c|}
\hline & \multirow{3}{*}{\multicolumn{2}{|c|}{ Observed }} & \multicolumn{3}{|c|}{ Predicted } \\
\hline & & & \multicolumn{2}{|c|}{ Credit } & \multirow{2}{*}{ Percentage Correct } \\
\hline & & & 0 & 1 & \\
\hline \multirow[t]{3}{*}{ Step 1} & \multirow{2}{*}{ Credit } & 0 & 18 & 28 & 39.1 \\
\hline & & 1 & 13 & 136 & 91.3 \\
\hline & \multicolumn{3}{|c|}{ Overall Percentage } & & 79.0 \\
\hline
\end{tabular}

a. The cut value is .500

Other factors included in the analysis have not showed any significant effect on the decision of banks to lend to firms. The manufacturing sector appears to be less preferred by banks for lending compared to the trade sector. Besides the manufacturing sector, exporting firms have less likelyhood to obtain banks to lend in Kosovo. From a logical connection that exporting firms are firms that belong only manufacturing sector and both these factors are not significant for firms in obtaining bank loans, it should be a matter of concern for policy makers in Kosovo. 
Having written a business plan seems not to be an important factor to acquiring loan, although this is a necessary condition for obtaining credit from a bank in Kosovo. Also credited to a firm does not affect whether its activity is spread in urban or rural area. Plans to increase employment have a slight effect but not a significant factor for obtaining loan from a firm.

Table 7 : The impact of different factors to firm in obtaining banks loan

\begin{tabular}{|ll|l|l|l|l|l|l|}
\hline & B & S.E. & Wald & df & Sig. & Exp(B) \\
\hline Step 1a & Manufacture & 1.376 & .881 & 2.438 & 1 & .118 & 3.959 \\
Trade & 1.612 & .468 & 11.861 & 1 & .001 & 5.012 \\
Service & 2.041 & .575 & 12.610 & 1 & .000 & 7.695 \\
Export & -.170 & 1.409 & .015 & 1 & .904 & .844 \\
Import & 3.287 & 1.171 & 7.882 & 1 & .005 & 26.754 \\
Performance & .835 & .407 & 4.204 & 1 & .040 & 2.304 \\
BusPlan & .235 & .448 & .275 & 1 & .600 & 1.265 \\
Employment Growth & -.746 & .504 & 2.189 & 1 & .139 & .474 \\
Urban & .424 & .587 & .522 & 1 & .470 & 1.528 \\
Constant & -.897 & .648 & 1.915 & 1 & .166 & .408 \\
\hline
\end{tabular}

a. Variable(s) entered on step 1: Manufacture, Trade, Service, Export, Import, Perfomance, BusPlan, NewEmployment and Urban.

Results from the table show that if the firm belongs to the trade sector the opportunity to take bank loans grow to about 5 times, and if the firm belong to service sector the opportunity would be increased 7.7 times, while firms experiencing business improvement adds to the possibility of obtaining credit for 2.3 times and finally, most importantly if the firm is importing of goods or raw material increases the possibility to get loan for 26.7 times.

\section{Conclusions}

The banking sector is the most stabldeveloped sectors in Kosovo e. Firms in Kosovo have experienced a decline in investment activities in the last 3-4 years. At least $20 \%$ of firms have been investing activities have access to bank loans, which appear to be small firms. Even about $24.5 \%$ of small firms that applied for loans were rejected, compared with only 1 medium firm refused and none of the big firms included in the sample. At the firms also exists a self-selection in the case of not applying for loans even though they need, and that this reluctance of firms is primarily due to the high interest rates, lack of collateral and delivery impossibility of securing documents and conditions requiring banks.

From the research results that small and medium firms on average finance their investments by bank loans by 13.6 percentage points less than large firms, therefore small firms should be directed to the family and friends for funding, and this category participate $8.2 \%$ on average in their financial sources. Differences of firm' size observed in terms of length of loan repayment, as smaller firms lower duration and vice versa, and the value of collateral to offer small firms provide collaterals on average three times the value of the loan, while medium firms offer 1.4 times the value of collateral loan.

Based on econometric model found that firm size, measured by number of employees, has significant impact on access to bank loans. Firm size has a strong positive correlation with access to bank loans. For every worker more, the chances of the firm to access bank loans increase by a factor of 1.248. Besides size, other factors that impact the firms to access bank loans are if firms develop activity in the sector of trade and services, then import and firm performances. Imports have higher factor of 26.7 times to influence a firm to get bank loans. From the findings we can draw two pararlele. The first, being the significant factor contributing in getting bank loans of the import and trade sector reflects the Kosovo economy 
orienting toward imports. The second, which can be noted is the finding that the manufacturing sector and exports are not contributing factors in obtaining bank loans, based on the fact that the export is typical characteristic of manufacturing enterprises, then this finding raises concern about the position of manufacturing firms, so it should be the signal for policy makers in Kosovo to address this issue.

\section{Bibliograpgy}

Bibliograpgy

Bajçinca, E. Financimi i NVM-ve në Kosovë. Cilat janë mundësitë? UET/PRESS, Revista shkencore ECONOMICUS, nr.10, Verë 2013, fq 81-96;

CBK (2014), Report of Financial Stability No.4, Central Bank of Republic of Kosovo, Prishtina. www.bqk-kos.org CBK (2014): The Quarter Assesment of Economy No. 5, TM4 2013, Central Bank of Republic of Kosovo, Prishtina. www.bqk-kos.org

BSC Kosovo 2011, 2012, 2013, Research Reports from survey with SME in Kosovo;

BSC Kosovo, Survey with firms in Kosovo 2010, 2011, 2012.

Carpenter, R. E. \& Petersen, B.C., Is the Growth of Small Firms Constrained by Internal Finance?

Krasniqi, B. A., Are small firms really credit constrained? Empricial evidence from Kosova. Int Enterp Manag Jurnal (2010) 6:459-479;

Krasniqi, B. A., Metodat Kërkimore në shkenca sociale, Dispensë. Instituti për ndërmarrësi dhe biznes të vogël. Prishtinë, 2012

Stigliz, J.E., Weiss A., Credit rationing in markets with imperfect information, The American Economic Review, Volume 71, Issue 3 (Jun., 1981), 393-410;

Thorsten Beck and Asli Demirguc-Kunt, February 2006. Small and Medium Size Enterprises: Acces to Finance as a Growth Constraint

Thorsten Beck, May 2007; Financing Coinstraints of SMEs in Developing Countries: Evidence, Determinants and Solutions 